\title{
DAMPAK PENGGUNAAN TEKNOLOGI WEBSITE TERHADAP PENINGKATAN KUALITAS LAYANAN PUBLIK PADA KANTOR CAMAT KADIA KOTA KENDARI
}

\author{
${ }^{1}$ Ulfah Attamimi, ${ }^{2}$ Riston G. Ahmad. \\ 1,2 IImu Pemerintahan Fakultas IImu Sosial dan IImu Politik \\ Universitas Muhammadiyah Kendari. \\ ulfah.fisipumk@gmail.com, griston9@gmail.com \\ Kendari, Indonesia
}

\begin{abstract}
This study aims to provide an overview of the impact of technology use, namely the website at the Kadia sub-district office in the framework of improving the quality of public services. The research method used is a qualitative method with a triangulation approach, namely observation, interviews, and written or archived data. The results show that the use of website technology in Kadia sub-district is a strategic step in responding to challenges in the era of governance development and improving the quality of digital technology-based public services. Ease of information dissemination and data integration between villages and districts are advantages that should facilitate public access. This situation should be able to change the mindset of all parties, both government officials and the public, which will lead to a more effective and efficient quality of public services. However, the impact of website technology has not yet been seen on improving the quality of public services. this is because the public's knowledge is still low regarding the existence of the sub-district website and how to use it, and also the lack of socialization of the sub-district website by the sub-district government to the Kadia community.
\end{abstract}

Keywords: District government; Public services; Quality of service; Website technology

\begin{abstract}
Abstrak
Penelitian ini bertujuan memberikan gambaran bagaimana dampak penggunaan teknologi yakni website pada kantor Camat Kadia dalam kerangka peningkatan kualitas layanan publik. Metode penelitian yang dipakai menggunakan jenis metode kualitatif dengan pendekatan triangulasi yaitu observasi, wawancara, dan data tertulis atau arsip. Hasil penelitian menunjukan bahwa penggunaan teknologi website di kecamatan Kadia merupakan suatu langkah strategis dalam menjawab tantangan di era perkembangan tata kelola pemerintahan dan peningkatan kualitas layanan publik berbasis teknologi digital. Kemudahan penyebaran informasi dan integrasi data antara kelurahan dan kecamatan adalah keunggulan yang seharusnya mempermudah akses publik. Keadaan ini seharusnya mampu mengubah mindset seluruh pihak baik aparatur pemerintahan maupun masyarakat yang akan mengarah pada kualitas layanan publik yang lebih efektif dan efisien. Namun belum terlihat dampak teknologi website terhadap peningkatan kualitas layanan publik. hal ini disebabkan karena pengetahuan publik masih rendah terkait keberadan website kecamatan dan bagaimana menggunakannya, dan juga masih minimnya sosialisasi website kecamatan yang dilakukan oleh pemerintah kecamatan kepada masyarakat Kadia.
\end{abstract}

Kata Kunci: Kualitas pelayanan; pelayanan Publik; Pemerintah Kecamatan; Teknologi Website

Open Access at: http://ojs.uho.ac.id/index.php/PUBLICUHO/index

Journal Publicuho is licensed under a Creative Commons Attribution 4.0 International License. 


\section{Journal Publicuho}

ISSN 2621-1351 (online), ISSN 2685-0729 (print)

Volume 3 Number 3 (August-October), (2020) pp.372-380

\section{PENDAHULUAN}

Adopsi teknologi dalam menunjang aktivitas pemerintahan telah lama dicanangkan oleh pemerintah pusat. Berdasarkan instruksi presiden No. 3 tahun 2003 bahwa penerapan egovernment diawali dengan membangun situs web pada setiap instansi pemerintahan. Konsep ini diharapkan mampu mengurai berbagai hambatan dalam proses birokrasi dan membentuk jaringan sistem manajemen serta proses kerja organisasi pemerintahan yang bekerja secara terpadu sehingga akan memudahkan terlaksananya proses pelayanan publik dan akses informasi. Perkembangan teknologi informasi juga memberikan kontribusi dalam mendukung efektivitas pemanfaatan website sehingga masyarakat semakin mudah mengakses aktivitas yang dijalankan oleh lembaga pemerintahan (Aprilia et.all, 2014)

E-government adalah penggunaan teknologi informasi yang dapat meningkatkan hubungan antara pemerintah dan pihak-pihak lain (Junaedi, 2005). E-government menunjuk pada penggunaan teknologi komunikasi dan informasi, terutama internet, untuk memberikan pelayanan dan pengiriman informasi pemerintah. Melalui e- government, pemerintah akan dikelolah melalui jaringan teknologi dan berbasis data untuk berbagai kepentingan yang bertujuan untuk memberikan pelayanan kepada masyarakat (Tarifu, L. (2020).

Upaya ini juga sebagai tindak lanjut pasca berlakunya Undang-Undang Nomor 14 tahun 2008 tentang Keterbukaan Informasi Publik, sebagai payung hukum bagi masyarakat dalam mengakomodir rasa ingin tahu mereka terhadap aktivtas pemerintahan. Dengan demikian, media website telah menjadi sarana yang sangat dibutuhkan. Yang mana pemanfaatannya bisa ditujukan sebagai media promosi produk-produk lokal daerah, sarana layanan pemenuhan kebutuhan informasi masyarakat, maupun sebagai media untuk menyampaikan usulan, kritik dan keluhan (Damanik dan Purwaningsih, 2017).

Implementasi kebijakan ini juga dilaksanakan oleh pemerintah Kecamatan Kadia Kota Kendari yang telah memanfaatkan teknologi website dalam menunjang aktivitas pemerintahannya. Melalui domain www.kecamatankadia.web.id, diharapkan masyarakat bisa dengan mudah mengakses data dan informasi berkaitan dengan aktivitas pemerintahan Kecamatan Kadia. Namun belum diketahui sejauhmana dampak penggunaan teknologi website ini memberikan efek positif dalam menunjang aktivitas pemerintah Kecamatan Kadia khususnya terhadap peningkatan layanan publik dalam rangka mencapai salah satu visinya sebagai lembaga pemerintah yang menerapkan pelayanan secara elektronis (e-government) serta peningkatan mutu pelayanan kepada masyarakat melalui pemanfaatan teknologi telematik. 


\section{Ulfah Attamimi, Riston G. Ahmad}

Permasalahan dalam penelitian ini adalah bagaimanakah dampak penggunaan teknologi website terhadap peningkatan kualitas layanan publik pada kantor camat Kadia kota Kendari?

Untuk memberikan pemahaman yang sama, berikut dijelaskan beberapa subtansi konseptual terkait dampak penggunaan teknologi yakni website pada kantor Camat Kadia.

Website merupakan kumpulan dari halaman-halaman yang berhubungan dengan file-file lain yang saling terkait. Dalam sebuah website terdapat satu halaman yang dikenal dengan sebutan homepage. Homepage adalah sebuah halaman yang pertama kali dilihat ketika seseorang mengunjungi sebuah website. (Risky dkk.,2013).

Pengembangan website adalah salah satu aspek yang paling penting dari situs web apapun, sebagai pengembangan dari situs yang bekerja pada coding dan pemrograman untuk membuat web page bekerja dengan baik. Sementara pembangun site gratis dapat hadir dengan cara membuat site sendiri. Tidak hanya pada website yang akan dikembangkan sesuai selera, tetapi akan dibuat sehingga dapat dengan mudah bekerja dengan CMS untuk menjalankan semua aspek yang berbeda dari website yang telah dibuat. Website dinamis adalah sebuah website yang isi kontennya dapat berubah mengikuti dari isi database. Seseorang tidak perlu mengganti pemrograman website melainkan cukup melakukan pembaharuan pada database yang digunakan (Rahman, 2013). selanjutnya dalam penggunaan teknologi informasi dan komunikasi dalam pemerintahan (egovernment), United Nation Development Program (UNDP), sebagaimana dikutip Emil A. Lagut menyatakan good governance adalah suatu kesepakatan menyangkut pengaturan negara yang diciptakan bersama oleh pemerintah, masyarakat madani dan sektor swasta demi terwujudnya kesejahteraan sosial (Susanto, 2010).

Pembangunan bukanlah kegiatan yang dilaksanakan oleh pemerintah untuk masyarakatnya, melainkan kegiatan yang dilaksanakan pemerintah bersama dengan seluruh masyarakatnya. Esensi kegiatan pembangunan adalah terjadinya perubahan sikap untuk memproyeksikan diri ke dalam situasi lain dan karena itu secara sadar dan terencana menyiapkan diri untuk melakukan perubahan untuk memperbaiki mutu hidupnya guna mengantisipasi keadaan dan perubahan yang akan terjadi di masa mendatang (Mardikanto \& Soebianto 2013). Bentuk partisipasi masyarakat dalam pembangunan meliputi partisipasi dalam pengambilan keputusan dan perencanaan kegiatan, pelaksanan kegiatan, pemantauan dan evaluasi, serta pemanfaatan hasil pembangunan.

Praditya (2013) melakukan Analisis SWOT terhadap pembangunan bidang TIK dalam menunjang program kerja instansi pemerintahan. Salah satu permasalahan yang ditemukan yaitu masih adanya masyarakat pedesaan yang kesulitan dalam mengakses informasi pembangunan melalui media internet (website), karena tingkat literasi TIK masyarakat pedesaan masih rendah, hal tersebut juga menjadi hambatan masyarakat pedesaan untuk 


\section{Journal Publicuho}

ISSN 2621-1351 (online), ISSN 2685-0729 (print)

Volume 3 Number 3 (August-October), (2020) pp.372-380

memberikan aspirasi melalui media TIK. Strategi yang ditawarkan untuk meningkatkan pelayanan instansi terkait yaitu menyediakan layanan sms melalui telepon genggam yang sudah dimiliki oleh semua lapisan masyarakat untuk menyampaikan aspirasi atau laporan/masukan kepada pemerintah.

Menurut Rusli dalam Holle (2011), secara konseptual, konsep dasar dari e-government sebenarnya adalah bagaimana memberikan pelayanan melalui elektronik (e-service), seperti melalui internet, jaringan telepon seluler dan komputer, serta multimedia, melalui pengembangan e-government ini, dilakukan pula penataan sistem manajemen informasi dan proses pelayanan publik dan mengoptimalkan pemanfaatan teknologi informasi dan komunikasi. Jadi dari persektif komunikasi, e-Government merupakan pemanfaatan media komunikasi berbasis internet oleh pemerintah untuk menyampaikan pesan pembangunan kepada masyarakat yang lebih luas dan mendapatkan umpan balik lebih cepat.

Harapannya adalah penggunaan teknologi informasi dan komunikasi dalam pemerintahan dapat menyelesaian memberikan konstribusi terhadap peningkatan pelayanan publik.

Pelayanan publik dapat diartikan sebagai pemberian layanan (melayani) keperluan orang atau masyarakat yang mempunyai kepentingan pada organisasi itu sesuai dengan aturan pokok dan tata cara yang telah ditetapkan. Pemerintahan pada hakekatnya adalah pelayanan kepada masyarakat, Tidak dapat untuk melayani dirinya sendiri, tetapi untuk melayani masyarakat serta menciptakan kondisi yang memungkinkan setiap anggota masyaraakat mengembangkan kemampuan dan kreativitasnya demi mencapai tujuan bersama.

Pelayanan umum oleh Lembaga Administrasi Negara diartikan sebagai segala bentuk kegiatan pelayanan umum yang dilaksanakan oleh Instansi Pemerintah di Pusat, di Daerah dan di lingkungan Badan Usaha Milik Negara/Daerah dalam bentuk barang dan atau jasa baik dalam rangka upaya kebutuhan masyarakat maupun dalam rangka pelaksanaan ketentuan peraturan perundang-undangan. Pelayanan publik dengan demikian dapat diartikan sebagai pemberian layanan (melayani) keperluan orang atau masyarakat yang mempunyai kepentingan pada organisasi itu sesuai dengan aturan pokok dan tata cara yang telah ditetapkan. (Safrudin, 2014).

Pelayanan publik merupakan suatu tolok ukur kinerja pemerintah yang paling kasat mata. Masyarakat dapat menilai langsung kinerja pemerintah berdasarkan pelayanan yang diterimanya. Untuk itu kualitas pelayanan publik di semua kementerian/lembaga adalah suatu hal yang mendasar yang harus segera ditingkatkan. Peningkatan pelayanan publik, KemenPAN RB menerapkan kebijakan bahwa sejak tahun 2014 adalah tahun inovasi pelayanan publik (Kurniawan, 2016). 
Adapun standar kualitas layanan publik diatur berdasarkan undang-undang No. 20 tahun 2009 pasal 20 tentang standar pelayanan, sebagai berikut:

1. penyelenggata berkewajiban menyusun dan menetapkan standar pelayanan dengan memperhatikan kemampuan penyelenggara, kebutuhan masyarakat, dan kondisi lingkungan.

2. Dalam menyusun dan menetapkan standar pelayanan sebagaimana dimaksud pada ayat (1), penyelenggara wajib mengikutsertakan masyarakat dan pihak terkait.

3. Penyelenggara berkewajiban menetapkan standar pelayanan sebagaimana dimaksud pada ayat (1). Pengikutsertaan masyarakat dan pihak terkait sebagaimana dimaksud pada ayat (2) dilakukan dengan prinsip tidak diskriminatif, terkait langsung dengan jenis pelayanan, memiliki kompetensi dan mengutamakan musyawarah, seta memperhatikan keberagaman.

Penyusunan standar pelayanan sebagaimana dimaksud pada ayat (1) dan ayat (2) dilakukan dengan pedoman tertentu yang diatur lebih lanjut dalam peraturan pemerintah, dan secara teknis ditindaklanjuti oleh pemerintah dibawahnya. Dalam kajian ini, ruang lingkup dibatasi pada wilayah kecamatan yaitu kantor camat Kadia Kota Kendari Sulawesi Tenggara.

Kecamatan merupakan salah satu perangkat daerah kabupaten/kota yang melaksanakan urusan pemerintahan yang menjadi kewenangan daerah, juga melaksanakan tugas pembantuan. Kecamatan selama ini diatur secara rinci melalui Peraturan Pemerintah No. 19 Tahun 2008 tentang Kecamatan. Namun setelah disahkannya UU No. 23 Tahun 2014 tentang Pemerintahan Daerah (UU Pemda), belum ada aturan pelaksanaan yang me- ngatur khusus tentang kecamatan.

Secara umum, pembahasan mengenai keca- matan relatif kurang mendapat perhatian. Kecamatan dianggap sebagai unit pemerintahan yang ambigu, menjadi perangkat daerah tapi juga mencakup kewilayahan. Seperti dinyatakan dalam UU 23 Tahun 2014 bahwa daerah kabupaten/kota dibagi atas kecamatan dan kecamatan dibagi atas kelurahan dan/atau desa (Pasal 2 ayat 2). Kecamatan sendiri adalah bagian wilayah dari daerah kabupaten/kota yang dipimpin oleh camat (Pasal 1 angka 24). Namun, camat sendiri tidak memiliki wewenang layaknya seperti kepala wilayah.

\section{METODOLOGI}

Penelitian ini menggunakan metode kualitatif, dengan pendekatan triangulasi data yang diperoleh dari hasil observasi, wawancara, dan data tertulis atau arsip. Informan ditentukan secara purposive sampling, terdiri dari Kepala Seksi E-Data dan E-Informasi Publik Kecamatan Kadia, Tim Pengelola Website, dan warga Kadia. Teknik analisis data dilakukan melalui tahapan sebagai berikut: 1) Reduksi data, yakni data yang diperoleh dari 


\section{Journal Publicuho}

ISSN 2621-1351 (online), ISSN 2685-0729 (print)

Volume 3 Number 3 (August-October), (2020) pp.372-380

wawancara atau melalui studi dokumen selanjutnya dilakukan proses analisis untuk mempertegas, memperpendek, membuat fokus, membuang hal yang tidak penting, dan mengatur data sehingga lebih mudah dimengerti dan dapat dibuat kesimpulan; 2) penyajian data, yakni suatu susunan informasi yang memungkinkan untuk diperoleh suatu kesimpulan penelitian. Prosesnya dengan mendeskripsikan data yang telah diperoleh melalui wawancara atau studi dokumen; 3) penarikan kesimpulan, merupakan tahapan setelah proses pengumpulan data berakhir. Sejak awal proses pengumpulan data dilakukan, peneliti sudah mulai berusaha memahami makna dari setiap temuan di lapang. Dengan demikian, tahapan penarikan kesimpulan sudah mulai dilakukan semenjak penelitian dimulai hingga proses pengumpulan data berakhir.

\section{HASIL DAN PEMBAHASAN}

\section{Dampak Penggunaan Teknologi Website Terhadap Peningkatan Kualitas Layanan Publik Pada Kantor Camat Kadia}

Sejak bulan November 2018, kantor Camat Kadia secara resmi telah meluncurkan laman situs (website) kecamatan Kadia dengan domain www.kecamatankadia.web.id. Hal ini merupakan suatu terobosan yang dilakukan oleh pemerintah kecamatan Kadia sebagai satu-satunya lembaga pemerintahan pada level kecamatan yang ada di kota kendari dalam menjawab tantangan perkembangan teknologi dan keterbukaan informasi di era digital.

Pemerintah kecamatan kadia membawahi lima kelurahan yaitu Anaiwoi, Bende Kadia, Pondambea, dan Wawowanggu. telah mengintegrasikan informasi kelurahan ke dalam website kecamatan. Data kelurahan yang ada diantaranya profil kelurahan, struktur organisasi pemerintah kelurahan, data penduduk, program kerja atau kegiatan yang berlangsung di kelurahan dan juga formulir yang berkaitan dengan kelengkapan berkas pelayanan publik. Dengan demikian, masyarakat bisa dengan mudah mengakses informasi yang berkaitan dengan kebutuhan layanan publik.

Penggunaan teknologi website bagi instansi pemerintah daerah dapat dikatakan sebagai salah satu media informasi kepada masyarakat. Hal ini juga terjadi pada pemerintah kecamatan Kadia yang memanfaatkan penggunaan website lebih banyak ditujukan sebagai sarana penyebarluasan informasi. Berdasarkan hasil wawancara dengan Bapak Bob Faizal (Kasi E-Data\&E-Informasi Publik, Kec. Kadia), dinyatakan sebagai berikut: "Website ini ditujukan agar masyarakat lebih tahu tentang profil kecamatan Kadia. juga sebagai sarana mempublikasikan kegiatan atau aktivitas yang berlangung di wilayah kecamatan sehingga masyarakat lebih mudah dan cepat mengakses informasi".

Kehadiran teknologi dalam tata kelola pemerintahan salah satunya agar mampu mewujudkan kemudahan dan meningkatkan kualitas dalam pelayanan publik. Namun 


\section{DAMPAK PENGGUNAAN TEKNOLOGI WEBSITE TERHADAP PENINGKATAN KUALITAS LAYANAN PUBLIK PADA KANTOR CAMAT KADIA KOTA KENDARI}

ISSN 2621-1351 (online), ISSN 2685-0729 (print

Volume 3 Number 3 (August-October), (2020) pp.372 -380

DOI: 10.35817/jpu.v3i3.14011

Ulfah Attamimi, Riston G. Ahmad

keadaan ini belum terasa secara menyeluruh di kecamatan Kadia. Temuan penelitian menunjukan pengetahuan publik masih rendah berkaitan dengan kehadiran website di kecamatan. Hasil wawancara dengan Ibu Milan (warga kel. Pondambea, 34 th): "saya tidak tahu tentang keberadaan website kecamatan. Bagus sekali kalau itu (website) sudah ada, jadi bisa lebih mudah dalam urusan pelayanan publik." Hal ini juga diperkuat dengan pengakuan ibu Titien (admin website): "perkiraan masyarakat umum yang mengetahui belum banyak sekalipun saat peluncuran website kami juga melakukan sosialisasi dan mengundang perwakilan masyarakat dari seluruh kelurahan yang ada di kecamatan Kadia." Adapun unsur masyarakat yang hadir adalah para kepala Puskesmas se kecamatan Kadia, Babikamtibmas, para lurah dan dinas Komunikasi dan Informasi. Harapannya agar mereka bisa menindak lanjuti informasi terkait website ini kepada masyarakat. (Wawancara dengan Bob Faizal, Kasi E-Data\&E-Informasi Publik, Kec. Kadia)

Oleh karena itu belum ada dampak yang signifikan sebagai akibat penggunaan website terhadap peningkatan kualitas layanan publik. Hal ini selain karena masih banyak masyarakat yang belum mengetahui keberadaan website kecamatan juga mereka belum menggunakannya secara optimal. "pemanfaatan website hanya sekitar $30 \%$ karena kebanyakan masyarakat masih melakukan pengurusan (layanan publik) secara manual dan meminta bantuan kepada petugas dari pada menggunakan fasilitas website untuk mendownload berkas, memprint dan membawanya ke kantor kecamatan. Mereka lebih cenderung untuk langsung datang ke kantor dan memanfaatkan fasilitas pelayanan publik yang ada." (Wawancara dengan Titien, admin website).

Hal ini juga terlihat dari jumlah rata-rata pengunjung website yang belum banyak. Temuan penlitian memperlihatkan bahwa dari jumlah total penduduk kecamatan Kadia sebanyak 50.175 jiwa, rata-rata pengunjung website hanya 50 orang setiap pekan, inipun tidak bisa dideteksi apakah warga Kadia yang mendominasi atau tidak sebab jangkauan website yang luas hingga mencakup ke seluruh dunia sehingga memperlihatkan ada 10 negara yang pernah mengakses website ini. "Selama ini yang benar-benar memanfaatkan website adalah LPM kelurahan dan para mahasiswa yang membutuhkan data dan informasi yang berkaitan dengan kecamatan Kadia, sebab kami selalu mengarahkan mereka membuka website ketika membutuhkan data tersebut." (Wawancara dengan Bob Faizal, Kasi E-Data\&E-Informasi Publik, Kec. Kadia)

Berdasarkan uraian di atas nampak bahwa keberadaan website di kecamatan Kadia belum memberikan dampak yang berpengaruh dalam peningkatan kualitas layanan publik. Masyarakat masih terbiasa dengan pola lama yaitu dengan mengunjungi langsung kantor kecamatan dalam rangka aktivitas layanan publik. Sekalipun pada website kebutuhan berkas untuk urusan layanan publik telah tersedia. Selain itu, sosilisasi kepada masyarakat masih perlu ditingkatkan sebab masih banyak warga masyarakat Kadia yang belum 


\section{Journal Publicuho}

ISSN 2621-1351 (online), ISSN 2685-0729 (print)

Volume 3 Number 3 (August-October), (2020) pp.372-380

Accredited SINTA SK.NOMOR 28/E/KPT/2019

mengetahui keberadaan website ini sehingga ke depan pemanfaatannya bisa lebih optimal dan kemudahan layanan publik bisa tercapai.

\section{KESIMPULAN}

Berdasarkan hasil penelitian dan pembahasan, maka dapat ditarik beberapa kesimpulan sebagai berikut:

1. Kehadiran website di kecamatan Kadia merupakan suatu langkah strategis dalam menjawab tantangan di era perkembangan tata kelola pemerintahan dan peningkatan kualitas layanan publik berbasis teknologi digital. Kemudahan penyebaran informasi dan integrasi data antara kelurahan dan kecamatan adalah keunggulan yang seharusnya mempermudah akses publik. Keadaan ini sejatinya akan mengubah mindset seluruh pihak baik aparatur pemerintahan maupun masyarakat yang akan mengarah pada kualitas layanan publik yang lebih efektif dan efisien.

2. Belum terlihat dampak teknologi website terhadap peningkatan kualitas layanan publik. hal ini disebabkan karena pengetahuan publik masih rendah terkait keberadan website kecamatan dan bagaimana menggunakannya, dan juga masih minimnya sosialisasi website kecamatan yang dilakukan oleh pemerintah kecamatan kepada masyarakat Kadia. .

\section{SARAN}

1. Perlu diadakan sosialisasi secara terorganisir kepada seluruh masyarakat Kadia berkaitan dengan keberadaan website kecamatan dan bagaimana cara mempergunakannya untuk kebutuhan layanan publik. Bentuknya bisa berupa pertemuan dengan perwakilan kelurahan yang terdiri dari unsur RT, RW, LPM, Karang Taruna, ibu-ibu Dasa Wisma, Majelis Taklim, dan lain-lain. Hal ini selain akan memberikan pengaruh dalam peningkatan pengetahuan publik terkait keberadaan website juga akan meningkatkan visitor website.

2. Optimalisasi penggunaan website oleh pemerintah kecamatan Kadia agar fungsi website tidak sekedar sebagai ruang publikasi informasi kecamatan dan kelurahan namun benarbenar dapat memberikan pengaruh terhadap peningkatan kualitas layanan publik. 


\section{DAFTAR PUSTAKA}

Damanik MP, Purwaningsih, 2017. E Government dan Aplikasinya di Lingkungan Pemerintah daerah. Jurnal Studi Komunikasi dan Media. Vol 21. No.2 Juli-Des 2017. Hal : 151 164.

Kurniawan RC. 2016. Inovasi Kualitas Pelayanan Publik Pemerintah Daerah. http://jurnal.fh.unila.ac.id/index.php/fiat. Vol. 10. No.3. Hal : 569 - 585.

Mardikanto T. Soebianto P. 2013. Pemberdayaan Mayarakat dalam Perspektif Kebijakan Publik. Bandung (ID): Penerbit Alfabeta

Mayriayanti, Risky, dan Sukadi Bambang Eka Putra Purnama. 2013. Aplikasi Pengelolaan Jurnal Online Pada Sekolah Tinggi Keguruan dan IImU Pengetahuan (STKIP) PGRI Pacitan. Indonesia Journal on Networking and Scurity

Praditya D. 2013. Pembangunan teknologi informasi dan komunikasi (TIK) dalam menunjang program kerja. J Penelitian Komunikasi. [http://jurnal. kominfo. go.id/index.php/jpk/article/vi ew/115

Rahman, Su. 2013. Cara Gampang Bikin CMS PHP Tanpa Ngoding. Jakarta: Mediakita.

Holle E. 2011. Pelayanan publik melalui electronic government: upaya meminimalisir praktek maladministrasi dalam meningkatan public service. J Sasi [internet]. ejournal.unpatti.a c.id/ppr_iteminfo_Ink.php?id=104

Shafrudin, Hadi. (2014). "Analisis Indeks Kepuasan Masyarakat (IKM) di RSUD Jendral Ahmad Yani Kota Metro". Skripsi. Bandar Lampung; FISIP UNILA

Susanto, Eko Harry. (2010). Kelambanan Reformasi Birokrasi dan Pola Komunikasi Lembaga Pemerintah. Jurnal ASPIKOM Volume 1, Nomor 1, Juli 2010: 1-124.

Tarifu, L. (2020). Implementasi Sistem Informasi Administrasi Kependudukan Dalam Pelayanan Kartu Tanda Penduduk Pada Dinas Kependudukan Dan Catatan Sipil Kota Kendari. Journal Publicuho, 3(2), 233. https://doi.org/10.35817/jpu.v3i2.1251 1 